\title{
Allelic diversity in populations of Solanum lycocarpum A. St.-Hil (Solanaceae) in a protected area and a disturbed environment
}

Tânia Maria de Moura ${ }^{1,7}$, Alexandre Magno Sebbenn², Karina Martins ${ }^{3}$, Maria Andreia Moreno, Giancarlo Conde Xavier Oliveira ${ }^{5}$, Lázaro José Chaves $^{6}$ and Paulo Yoshio Kageyama ${ }^{4}$

Recebido em 16/11/2010. Aceito em 30/09/2011

\begin{abstract}
RESUMO
(Diversidade alélica em populações de Solanum lycocarpum A. St.-Hil (Solanaceae) em Unidade de Conservação e em ambiente sob influência antrópica). O presente trabalho teve por objetivo comparar a diversidade genética em populações de Solanum lycocarpum A.St.-Hil, em ambientes naturais e antropizados, sob a hipótese de que Unidades de Conservação abrigam maior diversidade genética que áreas antropizadas. Para isso foram estudadas duas populações da espécie, uma situada em uma Unidade de Conservação, o Parque Estadual da Serra de Caldas Novas (PESCAN) em Caldas Novas/GO e outra situada em uma área de pastagem no município de Morrinhos-GO. As populações distanciam-se em $41 \mathrm{~km}$. Foram amostrados 60 indivíduos de cada população e os mesmos foram genotipados com cinco locos microssatélites (SSR). Pode-se registrar a maior número de alelos na população de S. lycocarpum situada na unidade de conservação, quando comparada à outra localizada em ambiente antropizado. Na população natural ocorreram onze alelos exclusivos e cinco raros, enquanto que na antropizada foram registrados três alelos exclusivos e um raro. Embora não tenha sido observada endogamia significativa nas populações, a divergência genética entre as mesmas foi alta $\left(G_{S T \text { (Hedrick) }}=0.147\right)$, para uma planta com dispersão a longas distâncias. Os resultados corroboram a hipótese, mostrando que a população sob menor influência antrópica abriga maior diversidade alélica, e confirmam a eficiência das Unidades de Conservação para a preservação da diversidade genética da espécie.
\end{abstract}

Palavras-chave: cerrado, fluxo gênico, genética da conservação, diversidade genética

\begin{abstract}
(Allelic diversity in populations of Solanum lycocarpum A. St.-Hil (Solanaceae) in a protected area and a disturbed environment). This study aimed to compare the genetic diversity of populations of Solanum lycocarpum A.St.-Hil between natural and human disturbed environments, with the assumption that protected areas have greater genetic diversity than disturbed areas. For this study, two populations were sampled in Goiás State, Brazil. One was located in a conservation unit, Serra de Caldas Novas State Park, in the Caldas Novas municipality. The other was located in a pasture area in the municipality of Morrinhos. The two populations are $41 \mathrm{~km}$ apart. We sampled 60 individuals from each population, which were genotyped with five microsatellite loci (SSR). The highest number of alleles was recorded in the population of the conservation unit, where we found 11 exclusive and five rare alleles. In the disturbed area, we recorded only three exclusive alleles and one rare allele. Although we did not observe significant inbreeding in these populations, genetic divergence between them was high $\left(G_{S T \text { (Hedrick })}=0.147=0.147\right)$ for a species with long distance seed dispersal. The results corroborate the hypothesis that the population in the less disturbed area harbors greater allelic diversity. They also confirm the effectiveness of using protected areas to preserve the genetic diversity of the species.
\end{abstract}

Key words: cerrado, gene flow, conservation genetics, genetic diversity

\footnotetext{
${ }^{1}$ Universidade Estadual de Campinas, Instituto de Biologia, Programa de pós graduação em Biologia Vegetal, Campinas, SP, Brasil

${ }^{2}$ Instituto Florestal de São Paulo, São Paulo, SP, Brasil

${ }^{3}$ Universidade Federal de São Carlos, Departamento de Biologia, Sorocaba, SP, Brasil

${ }^{4}$ Universidade de São Paulo, Escola Superior de Agricultura 'Luiz de Queiroz', Departamento de Ciências Florestais, Laboratório de Reprodução e Genética de Espécies Arbóreas, Piracicaba, SP, Brasil

${ }^{5}$ Universidade de São Paulo, Escola Superior de Agricultura 'Luiz de Queiroz', Departamento de Genética, Piracicaba, SP, Brasil

${ }^{6}$ Universidade Federal de Goiás, Escola de Agronomia, Goiânia, GO, Brasil

${ }^{7}$ Autor para correspondência: tmariamoura@gmail.com
} 


\section{Introduction}

Solanum lycocarpum A. St.-Hil. is a typical and widely distributed shrub from the Brazilian Cerrado. It is andromonoecious, flowers and fruits throughout the year (Oliveira Filho \& Oliveira 1988) and the fruits have many seeds that easily and rapidly germinate (Vidal et al. 1999). Pollination is mostly by Xylocopa bees (Oliveira Filho \& Oliveira 1988) and the dominant seed disperser is the maned wolf (Chrysocyon brachyurus Illiger), which is capable of carrying the seeds over long distances (Courtenay 1994).

Solanum lycocarpum easily occupies disturbed areas, such as roadsides and pastures. Although its seeds are dispersed over long distances, its pollinators are capable only of short distance flights. Thus, the species is ideal for studying the genetic structure of populations, which was previously undertaken by Martins et al. (2006) and Moura et al. (2009). However, studies contrasting the population genetic structure in natural and disturbed areas have not been published. Still, the natural habitats of this species have been devastated in recent years because areas have been transformed into extensive monocultures. In order to develop efficient strategies of genetic conservation of this species, knowing the distribution of the genetic diversity of the remaining populations is crucial, because it permits the selection of populations for both in situ and ex situ conservation.

Although S. lycocarpum occurs in greater density in disturbed areas, this study hypothesized that protected and undisturbed areas harbor greater genetic diversity than disturbed ones. Thus, our goal was to describe the genetic structure of two populations of $S$. lycocarpum, comparing a disturbed environment with an undisturbed one to verify whether there is an effect of human disturbance on the genetic diversity of this species.

\section{Material and methods}

We studied two populations of S. lycocarpum in the southern region of Goiás State, in central Brazil. The disturbed population was located in an area of pasture $\left(17^{\circ} 55^{\prime}\right.$ S, $49^{\circ} 00^{\prime} \mathrm{W}$ ) in Morrinhos. The other consists of a natural (undisturbed) population, located in Serra de Caldas Novas State Park (Parque Estadual da Serra de Caldas Novas) in Caldas Novas ( $\left.17^{\circ} 46^{\prime} \mathrm{S}, 48^{\circ} 40^{\prime} \mathrm{W}\right)$. These populations are $41 \mathrm{~km}$ from each other.

Young leaves were collected from 60 individuals of each population. Genomic DNA extraction followed the CTAB procedure described by Ferreira \& Grattapaglia (1998). The SSR primers were developed for Capsicum spp. (Buso et al. 2000) and transferred to S. lycocarpum (Martins et al., 2006). A detailed description of the analysis of microsatellites can be found in Martins et al. (2006). Five loci were used in this study (Table 1). Genetic diversity was estimated using the software GDA (Lewis \& Zaykin 2000). Qui square tests were performed to verify the significance of the difference in number of alleles found between the populations. Estimates of genetic divergence between populations were: $\theta_{p}$ (GDA software; Lewis \& Zaykin, 2000) and $R_{S T}\left(R_{S T}\right.$ Calc version 2.2; Goodman, 1997); both with $95 \%$ confidence interval obtained by 1000 bootstrap resampling over loci. By comparison purposes, genetic differentiation between populations was also estimated using the statistic $G_{S T}$ (Hedrick) according to Hedrick (2005) and using the software GDA_NT (Degen, 2006). The historical gene flow Nm was estimated indirectly, according to the 'island model' proposed by Crow \& Aoki (1984). For results of other estimates of genetic diversity and spatial genetic structure see Moura et al. (2009).

\section{Results and discussion}

A higher number of alleles was detected in the undisturbed population of Serra de Caldas Novas State Park than in the disturbed population located in a pasture in Morrinhos. The Caldas Novas population had 26 alleles, 11 being exclusive and some having very low frequency (minimum of 0.009). The disturbed population (Morrinhos) had 18 alleles, 3 of which were exclusive and rare (frequencies varied from 0.008 to 0.025 ( Table 1). The number of alleles was significantly different between the populations $\left(\chi^{2}=6.03 ; p\right.$ $<0.05 ; d . f .=1)$. This showed that even a species commonly found in disturbed areas, such as pastures and roadsides, have a higher genetic diversity in undisturbed areas than in disturbed ones. Moura et al. (2009), studying the same populations, detected less spatial genetic structure in Serra de Caldas Novas State Park than in the pasture. These authors suggested that this result might have been due to the larger distance of seed dispersal in the park, leading to small levels of spatial genetic structure in this population.

Estimates of genetic divergence among populations were significantly higher than zero (Table 2), confirming that genetic drift has affected the genetic difference between the populations. The highest divergence was obtained by the unbiased $G_{S T \text { (Hedrick) }}$ estimator $\left(G_{S T \text { (Hedrick })}=0.147\right)$, showing that $85.3 \%$ of the genetic diversity is located within the populations. The estimate of historical gene flow among the populations was very low $(\mathrm{Nm}<1$, Table 2$)$.

As previously mentioned, Solanum lycocarpum occupies disturbed environments and is commonly found along roadsides, which possibly act as gene flow corridors, connecting populations (Martins et al. 2011). Thus, the significant genetic divergence between populations can demonstrate the effect of fragmentation on these populations, counteracting the potential effect of the corridors in facilitating gene flow. These populations are at a relatively small distance $(41 \mathrm{~km})$ from each other, which would not be expected to cause too much divergence, considering the dispersal biology of this species (the maned wolf can walk about $40 \mathrm{~km}$ per night). 
Table 1. Allele frequencies in five nuclear microsatellite loci, in two populations of Solanum lycocarpum in Goiás state. $\mathrm{n}$ is the sample size and the numbers in the second column are alleles, named by their length in bp (base pairs).

\begin{tabular}{|c|c|c|c|}
\hline \multirow{2}{*}{ Loci } & \multirow{2}{*}{ Sample/allele (bp) } & \multicolumn{2}{|c|}{ Populations } \\
\hline & & Pop1 - Morrinhos & Pop2 - Caldas Novas \\
\hline \multirow[t]{4}{*}{ CA23 } & $n$ & 60 & 58 \\
\hline & 98 & 0.092 & 0.147 \\
\hline & 100 & 0.283 & 0.302 \\
\hline & 102 & 0.625 & 0.552 \\
\hline \multirow[t]{3}{*}{ CA53 } & $n$ & 60 & 58 \\
\hline & 190 & - & 0.009 \\
\hline & 192 & 1.000 & 0.991 \\
\hline \multirow[t]{4}{*}{ CA144 } & $n$ & 52 & 56 \\
\hline & 86 & 0.779 & 0.464 \\
\hline & 88 & 0.221 & 0.509 \\
\hline & 90 & - & 0.027 \\
\hline \multirow[t]{20}{*}{ CA 158} & $n$ & 59 & 57 \\
\hline & 200 & 0.025 & - \\
\hline & 202 & 0.008 & - \\
\hline & 206 & - & 0.114 \\
\hline & 208 & 0.042 & 0.114 \\
\hline & 210 & 0.220 & 0.211 \\
\hline & 212 & 0.127 & 0.140 \\
\hline & 214 & 0.407 & 0.044 \\
\hline & 216 & 0.034 & 0.053 \\
\hline & 218 & 0.034 & 0.070 \\
\hline & 220 & 0.034 & 0.070 \\
\hline & 222 & 0.042 & 0.070 \\
\hline & 224 & - & 0.018 \\
\hline & 226 & - & 0.026 \\
\hline & 228 & - & 0.035 \\
\hline & 230 & 0.025 & - \\
\hline & 232 & - & 0.009 \\
\hline & 234 & - & 0.009 \\
\hline & 236 & - & 0.009 \\
\hline & 240 & - & 0.009 \\
\hline \multirow[t]{3}{*}{ CA161 } & $n$ & 60 & 56 \\
\hline & 173 & - & 0.009 \\
\hline & 178 & 1.000 & 0.991 \\
\hline Total number of alleles per population & & 18 & 26 \\
\hline Number of exclusive alleles per population & & 3 & 11 \\
\hline
\end{tabular}

Table 2. Estimates of genetic divergence between two populations of Solanum lycocarpum in Goiás state: Morrinhos (Pop1) \& Caldas Novas (Pop2).

\begin{tabular}{llll}
\hline Sample & $\theta p($ C.I. $)$ & $R_{S T}($ C.I. $)$ & $G_{S T \text { (Hedrick) }}$ \\
Populations & $0.080(0.001$ to 0.164$)$ & $0.039(0.024$ to 0.235$)$ & 0.147 \\
$N m$ & 0.72 & 1.54 & 0.36 \\
\hline
\end{tabular}

(C.I.) $95 \%$ confidence interval, estimated from 1000 bootstrap re-sampling across loci. 
The difference in the estimations of genetic divergence (Table 2) is due to differences in the calculation methods. $G_{S T \text { (Hedrick) }}$, estimated according to Hedrick (2005), was slightly higher than $\theta_{p}$ as estimated by Weir \& Cockerham's method (1984). Hedrick's method (2005) considers the type of alleles found in the populations and the allele frequencies, while Weir \& Cockerham's method (1984) considers only the variation in allele frequencies.

No significant inbreeding was detected in these populations (Moura et al. 2009), indicating that, although genetic drift may have caused genetic differentiation between the populations, probably a random mating system has occurred within populations. Despites the absence of inbreeding, the record of less than one migrant per generation between populations and loss of alleles in the disturbed environment can jeopardize the conservation of this species in the long run. Our results show the effectiveness of protected areas for in situ conservation of genetic diversity. Further studies are necessary regarding the genetic structure of plants of the Cerrado for implementation of effective conservation management plans.

In general, our results suggest that both populations must be conserved in situ. In addition, the pasture population must also be conserved ex situ, because of the occurrence of some exclusive alleles and its location in a very anthropogenic landscape.

\section{Acknowledments}

The authors thank Dr. João Renato Stehmmann (UFMG) and Dr. Vinícius Castro Souza (ESALQ/USP) for identifying the species studied. They also thank MSc. Denis Filer (Oxford University) for translating the paper.

\section{References}

Buso, G.S.C.; Brondani, R.V.; Amaral, Z.P.S.; Reis, A.M.M. \& Ferreira, M.E 2000. Desenvolvimento de primers SSR para análise genética de pimentas e pimentões (Capsicum spp.) utlizando biblioteca genômica enriquecida. Brasília, Embrapa/Cenargen. (Boletim de pesquisa 15).

Couternay, Y. 1994. Conservation of the Maned Wolf: Fruitful relations in a changing environment. Canid news 2: 41-43.

Crow, J.F. \& Aoki, K. 1984. Group selection for polygenic behavioral trait: estimating the degree of population subdivision. Proceedings of the National Academy of Sciences of United States of América. PNAS 81(19): 607-677.

Degen, B. 2006. GDA_NT 2006. Genetic data analysis and numerical tests. Grosshansdorf, Institute for Forest Genetics.

Ferreira, M.E. \& Grattapaglia, D. 1988. Introdução ao uso de marcadores RAPD e RFLP em análise genética. 3 ed. Brasília, Embrapa - Cenargen.

Goodman, S.J. 1997. RstCalc: a collection of computer programs for calculating estimates to genetic differentiation from microsatellite data and determining their significance. Molecular Ecology 6(9): 881-885.

Hedrick, P.W. 2005. A standardized genetic differentiation measure. Evolution 59(8): 1633- 1638.

Lewis, P.O. \& Zaykin, D. 2000. Genetic Data Analysis: Computer program for the analysis of allelic data. Version 1.0 (d15). Free program distributed by the author over the internet from the GDA. http://lewis. eeb.uconn.edu/lewishome/software.html (Acesso em 23/01/2007)

Martins, K.; Chaves, L.J.; Buso, G.S.C. \& Kageyama, P.Y. 2006. Mating system and fine-scale spatial genetic structure of Solanum lycocarpum St. Hill. (Solanaceae) in the Brazilian Cerrado. Conservation Genetics 7(6): 957-969.

Martins, K.; Chaves, L.J.; Vencovski, R. \& Kageyama, P.Y. 2011. Genetic structure based on nuclear and chloroplast microsatellite loci of Solanum lycocarpum A. St.-Hil (Solanaceae) in Central Brazil. Genetics and Molecular Research 10(2): 665-677.

Moura, T.M.; Sebbenn, A.M.; Chaves, L.J.; Coelho, A.S.G.; Oliveira, G.C.X. \& Kageyama, P.Y. 2009. Diversidade e estrutura genética espacial em populações fragmentadas de Solanum spp. do Cerrado, estimados por meio de locos microssatélites. Scientia forestalis 37(82): 143-150.

Oliveira Filho, A.T. \& Oliveira, L.C.A. 1988. Biologia floral de uma população de S. lycocarpum St. Hill. (Solanaceae) em Lavras MG. Revista Brasileira de Botânica 11(1/2): 23-32.

Vidal, M.C.; Stacciarini-Seraphin, E. \& Camara, H.H.L.L. 1999. Crescimento de plântulas de Solanum lycocarpum St. Hil. (lobeira) em casa de vegetação. Acta Botanica Brasilica 13(3): 271-275.

Weir, B.S. \& Cockerham, C.C. 1984. Estimating F-statistics of the analysis of populations structure. Evolution 38(6): 1358-1370. 